\title{
Effects of Dissolved Organic Matter on Sorption of Oxytetracycline to Sediments
}

\author{
Zongzhou Wang $\mathbb{D}^{1,2}$ Qianli Jiang $\mathbb{D}^{3}{ }^{3}$ Runze Wang, ${ }^{1,2}$ Xiaoyu Yuan $\mathbb{D},{ }^{1,2}$ \\ Shengke Yang $\mathbb{D}^{1,2}$ Wenke Wang $\mathbb{D}^{1,2}$ and Yaqian Zhao ${ }^{4}{ }^{4}$ \\ ${ }^{1}$ Key Laboratory of Subsurface Hydrology and Ecological Effects in Arid Region, Chang'an University, Ministry of Education, \\ Xian, Shaanxi 710054, China \\ ${ }^{2}$ School of Environmental Science and Engineering, Chang'an University, Xian, Shaanxi 710054, China \\ ${ }^{3}$ Weinan Institute of Environmental Science, Weinan, Shaanxi 714000, China \\ ${ }^{4}$ Dooge Centre for Water Resource Research, School of Civil Engineering, University College Dublin, Belfield, Dublin 4, Ireland
}

Correspondence should be addressed to Shengke Yang; ysk110@126.com

Received 25 October 2017; Revised 12 January 2018; Accepted 7 February 2018; Published 8 March 2018

Academic Editor: Meijing Zhang

Copyright (C) 2018 Zongzhou Wang et al. This is an open access article distributed under the Creative Commons Attribution License, which permits unrestricted use, distribution, and reproduction in any medium, provided the original work is properly cited.

\begin{abstract}
The effects of two representative dissolved organic matters (DOMs) (derived from corrupt plants (PDOM) and chicken manure $(\mathrm{MDOM})$ ) on sorption characteristic of oxytetracycline to three typical sediments (first terrace (FT), river floodplain (RF), and riverbed (RB) sediments collected from the Weihe River) were investigated. Results showed that both DOMs can make the adsorption equilibrium time advance about 6 hours. The presence of DOMs changed the sorption kinetics model and the spontaneous degree of the reaction but did not change the sorption isotherm models. The adsorption of oxytetracycline (OTC) could be promoted by adding PDOM, and its maximum adsorption amount increased by $23.8 \%$ for FT, $38.0 \%$ for RB, and $28.3 \%$ for RF, respectively, whereas MDOM could inhibit the adsorption and maximum adsorption amount decreased by $23.3 \%$ for FT, $11.6 \%$ for RB, and $16.1 \%$ for RF, respectively. In addition, the DOM concentration also affected the adsorption. Overall, this study suggests that the humus-like DOM can promote the adsorption of OTC while the protein-like DOM can inhibit the adsorption of OTC to sediments, which is determined by the aromaticity, hydrophilicity, and polarity of the DOMs.
\end{abstract}

\section{Introduction}

Antibiotics are widely used in aquaculture, poultry breeding, food processing, and pharmaceutical. However, they can not only cause organic pollution, but also threaten the safety of microbial communities, triggering resistance genes after being released into the environment. Lately the resistance genes have been detected in environmental media such as river water, sediment, groundwater, and soil [1-3]. Therefore, the study of environmental behavior of antibiotics to achieve risk prediction and management is of great significance.

The fate of antibiotics in the soil is mainly through adsorption, migration, transformation, and degradation. Among them, adsorption is one of the processes that profoundly affected the behavior of the antibiotics in soil and sediments. It was reported that the adsorption behavior of antibiotics was influenced by the soil type, composition and properties, $\mathrm{pH}$, and temperature conditions $[4,5]$. In addition, the interaction of antibiotics with some other coexistences, such as dissolved organic matter (DOM) and metal oxides, is also an important factor affecting the adsorption of antibiotics on soil [6]. A large number of studies have shown that the main substance to adsorb antibiotics in soil and sediments is its organic constituents. In other words, it is DOM that plays an important role in the migration of antibiotics. Therefore, identification of the effect of DOM on the adsorption of antibiotics in sediments will facilitate better understanding the mechanism of antibiotic adsorption and its transformation in unsaturated zone.

Previous studies reported that the source of DOM apparently influences the magnitude of sorption. Oh et al. [7] found that, for the effect of DOMs on ibuprofen sorption, citrate concentration increased and the $K_{d}$ value decreased 
but urea did not interrupt the ibuprofen sorption. The concentration of DOM also showed a different adsorption behavior of antibiotics to soil. Kulshrestha et al. [8] observed an increased sorption at a lower concentration of dissolved humic acid $(1 \mathrm{mg} / \mathrm{L})$, while a higher concentration of humic acid $(10 \mathrm{mg} / \mathrm{L})$ resulted in an opposite effect. Moreover, the variety of antibiotics can make significant influence on their adsorption behavior due to the difference of their properties $[4,9]$. So there should be some essential mechanism to dominate these apparently different results. It has been clearly demonstrated that DOM can form complexation with relatively polar pesticides or uptake hydrophobic organic contaminants, which increases the apparent aqueous solubility and potentially decreases the sorption [10-15]. However, it has been found that the presence of cow dung DOM promotes the adsorption of OTC on black soil and with the increasing of DOM concentration, the promoting effect is more evident. In addition, the presence of DOM will mask the adsorption sites to inhibit the adsorption of soil on oxytetracycline [16], while Ling et al. [17] reported that the binding of DOM to sediment particles also increased the organic carbon content and changed its surface morphology, resulting in an increase in the adsorption sites on the surface of the sediment and an increase in the adsorption of oxytetracycline. It has been demonstrated that the most important compositions of DOM include three categories: humic substances, polysaccharides, and proteins [18], while these substances should play an essential role on the adsorption of antibiotics by their hydrophobicity, aromaticity, and functionality properties. However, to our knowledge, very few studies showed solicitude or comparison to the distinct adsorption behavior caused by the humic and protein substances on the adsorption. At least, the effect on the adsorption of OTC still deserves investigation. The study of the mechanism of these kinds of DOMs affecting soil adsorption of antibiotics is obviously insufficient.

In this study, with the aim of investigating the effect of DOM on the sorption of OTC to sediments, three typical sediments (first terrace sediment, river floodplain sediment, and riverbed sediment) were collected from the Weihe River, Northwest China, and subjected for testing. Two typical DOMs were derived from corrupt plants and chicken manure. Elemental analysis and three-dimensional fluorescence were deployed to elucidate the mechanism of the effect of DOM on the adsorption of OTC to sediments.

\section{Materials and Methods}

\subsection{Sample Collection and Analysis}

2.1.1. Sample Collection and Pretreatment. The sampling sites are located at Guanzhong basin, middle reaches of the Weihe River. To make the study more representative, three sediments were collected from first terrace (FT), river floodplain $(\mathrm{RF})$, and riverbed (RB) along the Weihe River crosswise. Sediment samples were naturally air-dried, then sealed, and low temperature stored before use. Quartz, feldspar, mica, and other minerals can be found in the FT and RF sediment by SEM. Their characterization of sediments is showed in
Table 1. Corrupt plants were collected from the litters through natural corruption at the Weihe River bank, while chicken manure was obtained from a local poultry farming (with no use of antibiotics). All of the samples were detected with no OTC.

After collection, corrupt plants and chicken manure were subjected for DOMs extraction. To do so, $40 \mathrm{~g}$ of corrupt plants and chicken manure were placed in $400 \mathrm{~mL}$ distilled water, respectively, shaking at $200 \mathrm{rpm}$ and $25 \pm 1^{\circ} \mathrm{C}$ for $12 \mathrm{hrs}$. The suspensions were then centrifuged at $12000 \mathrm{rpm}$ and $4^{\circ} \mathrm{C}$ for $10 \mathrm{~min}$. Finally, the supernatant was filtered through a $0.45 \mu \mathrm{m}$ membrane and stored in the dark environment at a low temperature $\left(4^{\circ} \mathrm{C}\right)[19,20]$.

2.1.2. Analysis. Elemental $(\mathrm{C}, \mathrm{H}, \mathrm{N})$ analyses were conducted via a Vario ELIII elemental analyzer. The oxygen content was calculated by the mass difference. To assess the polarity and aliphatic characteristics of the sorbents, $(\mathrm{O}+\mathrm{N}) / \mathrm{C}$ and $\mathrm{H} / \mathrm{C}$ atomic ratios were calculated. The fluorescence spectra of DOM samples were also recorded at room temperature with a 700-V Xe lamp and a $1 \mathrm{~cm}$ quartz cell (F-7000; Hitachi, Japan). The excitation wavelengths (Ex) ranging from 220 to $600 \mathrm{~nm}$ and emission (Em) wavelengths ranging from 250 to $600 \mathrm{~nm}$ were used. The scan rate was $1200 \mathrm{~nm} / \mathrm{min}$.

2.2. Sorption Experiments. The sorption experiments were performed using an Organization for Economic Cooperation and Development (OECD) method. OTC was used as a representative antibiotic for adsorption experiments.

2.2.1. Sorption Kinetics. A preequilibrium kinetic experiment was carried out to determine the equilibrium time for batch reactions in order to study sorption isotherms. The reaction solutions in $10 \mathrm{~mL}$ centrifuge tubes containing three sediments $(0.25 \mathrm{~g})$ and $5 \mathrm{~mL}$ of OTC $(10 \mathrm{mg} / \mathrm{L})$ were initiated by spiking $1 \mathrm{~mL}$ of the following solutions, respectively: distilled water (without DOM) and the TOC concentration of $100 \mathrm{mg} / \mathrm{L}$ of PDOM and MDOM solution. The tubes were stirred continuously at a constant temperature of $25^{\circ} \mathrm{C}$ $(298 \mathrm{~K})$. At time intervals of $2,4,8,16,20,24,30,36,48$, 60 , and $72 \mathrm{hrs}$, three replicates were centrifuged at $10000 \mathrm{rpm}$ for $20 \mathrm{~min}$. The obtained supernatants were analyzed using UPLC to quantify the concentration of unabsorbed OTC. Control experiments without sediments were also conducted under the same conditions as blank.

2.2.2. Sorption Isotherms and Thermodynamics. In the batch experiments, sediments and DOMs were added in the same amount as sorption kinetics experiments described in Section 2.2.1, while the initial concentration of OTC ranged from $5.0 \mathrm{mg} / \mathrm{L}$ to $25.0 \mathrm{mg} / \mathrm{L}$. All samples were allowed to equilibrate in the tubes at a constant room temperature. After equilibrium was reached, $5 \mathrm{~mL}$ of the solutions from each tube was collected and centrifuged at $10,000 \mathrm{rpm}$ for $20 \mathrm{~min}$. The obtained supernatants were used to quantify the concentration of OTC. Reactions were conducted in duplicate for each sample. 
TABLE 1: Basic composition of first terrace (FT), river floodplain (RF), and riverbed (RB) sediments.

\begin{tabular}{|c|c|c|c|c|c|}
\hline \multirow[b]{2}{*}{ Samples } & \multirow[b]{2}{*}{ TOC (\%) } & \multicolumn{4}{|c|}{ Granulometric composition (\%) } \\
\hline & & $\begin{array}{c}\text { Silt } \\
<0.25 \mathrm{~mm}\end{array}$ & $\begin{array}{c}\text { Fine sand } \\
0.25-0.35 \mathrm{~mm}\end{array}$ & $\begin{array}{c}\text { Medium sand } \\
0.35-0.5 \mathrm{~mm}\end{array}$ & $\begin{array}{c}\text { Coarse sand } \\
>0.5 \mathrm{~mm}\end{array}$ \\
\hline FT & 6.032 & $7.5 \pm 4.7$ & $43.3 \pm 7.6$ & $42.6 \pm 5.8$ & $6.6 \pm 4.3$ \\
\hline $\mathrm{RB}$ & 4.184 & $5.3 \pm 1.4$ & $43.9 \pm 9.7$ & $42.9 \pm 4.2$ & $7.9 \pm 3.1$ \\
\hline $\mathrm{RF}$ & 1.575 & $21.7 \pm 3.8$ & $47.5 \pm 4.5$ & $23.1 \pm 6.2$ & $7.7 \pm 4.7$ \\
\hline
\end{tabular}

The sorption thermodynamics experiments were conducted at the temperature ranging from $25^{\circ} \mathrm{C}(298 \mathrm{~K})$ to $45^{\circ} \mathrm{C}$ $(318 \mathrm{~K})$, and the initial concentration of OTC ranged from $5.0 \mathrm{mg} / \mathrm{L}$ to $25.0 \mathrm{mg} / \mathrm{L}$. Other steps were the same as the sorption isotherms described in Section 2.2.2.

2.2.3. Effect of DOM Concentration on Sorption. Edge experiments were conducted to investigate the effect of DOM concentration on sorption. Briefly, $0.25 \mathrm{~g}$ sediments were weighed into a $10 \mathrm{~mL}$ centrifuge tubes and $1 \mathrm{~mL}$ of PDOM and $1 \mathrm{~mL}$ of MDOM with a series of DOM concentration (50, $100,150,200$, and $300 \mathrm{mg}$ TOC/L) were spiked. Then, $5 \mathrm{~mL}$ of OTC $(10 \mathrm{mg} / \mathrm{L})$ solution was added, stirring continuously at a constant temperature of $25^{\circ} \mathrm{C}$ for $30 \mathrm{hrs}$, and then centrifuged at $10000 \mathrm{rpm}$ for $20 \mathrm{~min}$; the obtained supernatants were used to quantify the concentration of OTC. The experiment without DOM was also conducted as blank.

2.3. Oxytetracycline Measurement. Ultrahigh performance liquid chromatography fitted with waters TUV detector (Waters UPLC H-Class) and ACQUITY UPLC BEH C18 $1.7 \mu \mathrm{m} 2.1 \times 150 \mathrm{~mm}$ Column was employed for detection and quantification of OTC. Column temperature was $40^{\circ} \mathrm{C}$ $\pm 0.1^{\circ} \mathrm{C}$ and sample $10^{\circ} \mathrm{C} \pm 0.1^{\circ} \mathrm{C}$. Injection volumes of $5 \mu \mathrm{L}$, a retention time of $1.530 \pm 0.003 \mathrm{~min}$, and a mobile phase of $60 \%$ acetonitrile $/ 40 \%$ water with a flow rate of $0.1 \mathrm{~mL} / \mathrm{min}$ were used. OTC was measured at $260 \mathrm{~nm}$.

\section{Results and Discussion}

3.1. Adsorption Characteristics of OTC to Sediments. Data obtained from the sorption experiments of OTC to three sediments showed that the adsorption amount gradually increased with time till equilibrium is reached (Figure 1). The equilibrium time of FT sediment is in $24 \mathrm{hrs}$ which is shorter than other two sediments. The maximum adsorption amount of three sediments followed the order: RF $>$ FT $>$ RB. According to the basic characteristics presented in Table 1, the TOC content of FT is greater than RB, which also means that the organic matter content of FT sediment is greater than RB. That is why the adsorption amount of FT is larger than RB. Chen et al. [21] reported that there is a positive correlation between organic matter content and sediment adsorption capacity. However, the amount of OTC adsorbed by the RF sediment is larger than that of the other two sediments because of its high content of silt in the sediment particle size distribution [22]. Laak et al. reported that the higher content of silt contains more clay minerals, more metal ions, and a

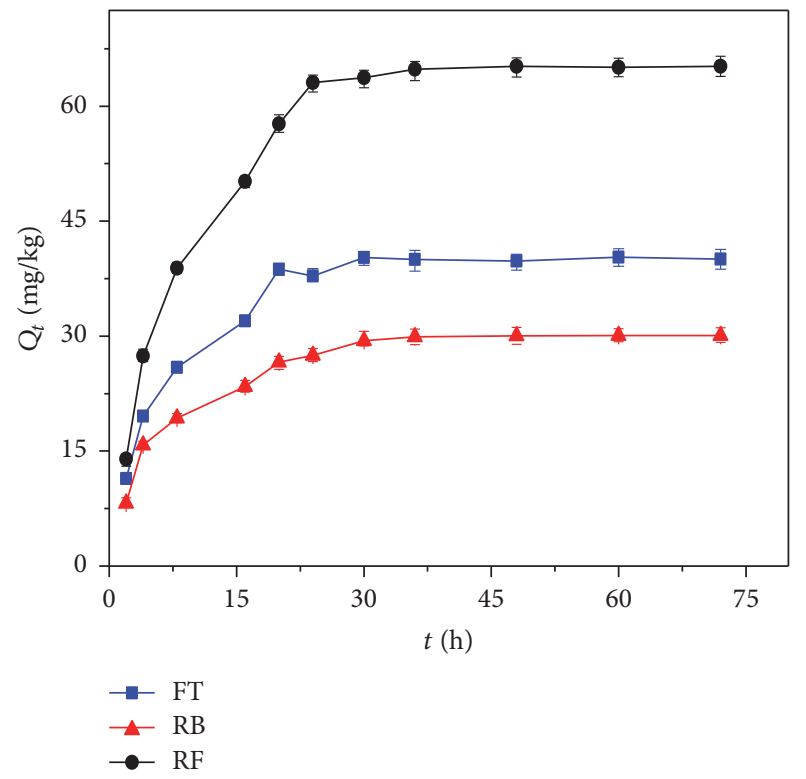

FIGURE 1: Adsorption characteristic of OTC to sediments.

larger cation exchange capacity. Interactions of exchangeable salt-based ions through the hydroxyl or dihydroxy sites with the cation in soil surface could enhance soil adsorption of OTC [23].

\subsection{Effect of DOM on the Adsorption of OTC to Sediments}

3.2.1. Effect on Sorption Kinetics. The adsorption kinetics of OTC to three sediments plotted in Figure 2 apparently showed that, before DOMs were added, the adsorption for three sediments is mainly divided into two phases, that is, the first phase for rapid adsorption in the first $8 \mathrm{hrs}$ and the second phase for slow adsorption; the equilibrium time is about in $30 \mathrm{hrs}$. After the DOMs were added, the rapid phase is still in the first $8 \mathrm{hrs}$, while the equilibrium time is significantly accelerated in $24 \mathrm{hrs}$, indicating that the presence of DOMs can promote the adsorption equilibrium time, which may be due to the activation of the adsorption sites of sediment particles, reduction of the activation energy, and increasing of the adsorption rate when the DOMs were added.

To investigate the adsorption reaction process of OTC to sediments, pseudo-first-order model and pseudo-secondorder model were used to fit the sorption kinetics data of OTC to sediments $[5,24,25]$. The adsorption trends are showed in Figure 2, while the corresponding fitting parameters are 

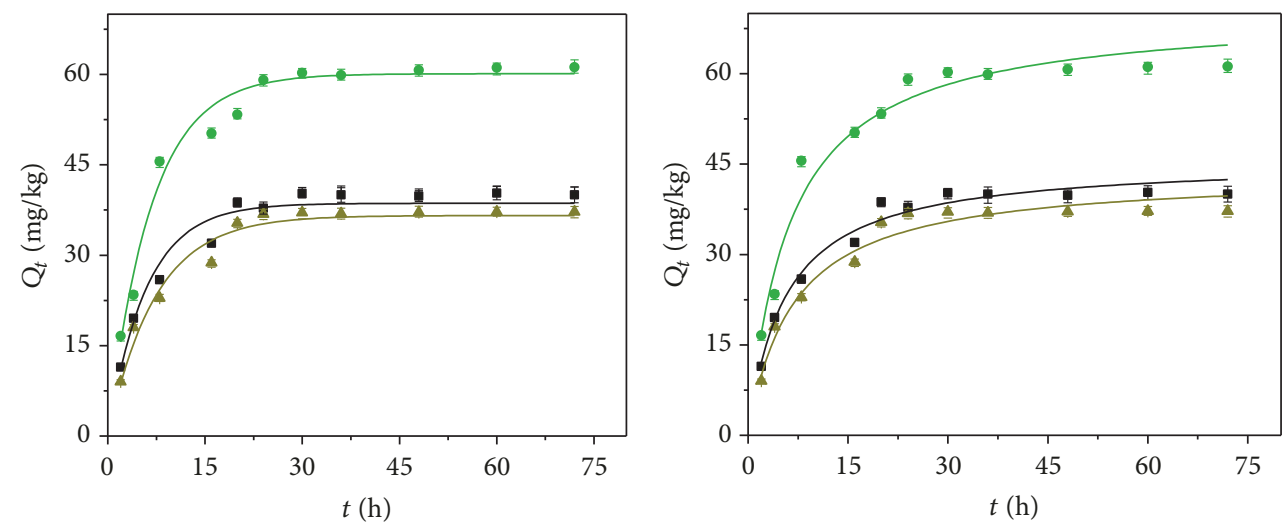

Pseudo-first-order model

— FT

— FT-PDOM

— FT-MDOM

(a)

Pseudo-second-order model

— FT

— FT-PDOM

— FT-MDOM

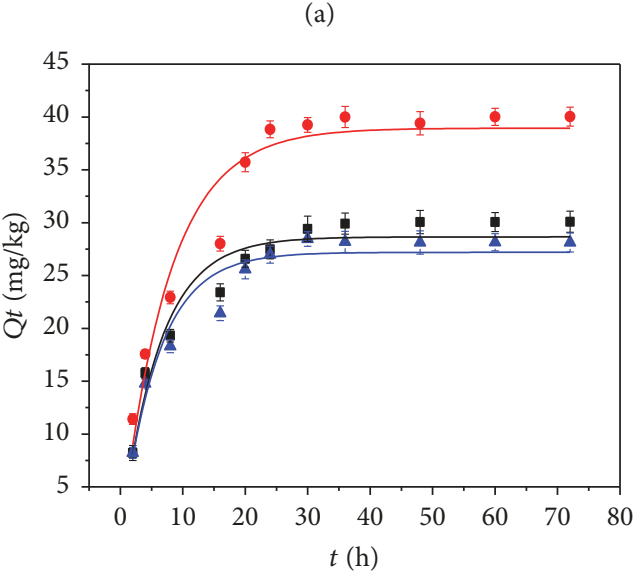

(b)

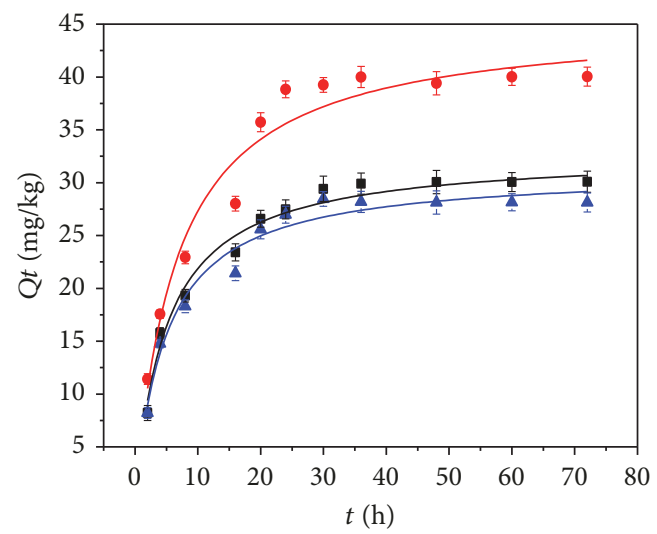

Pseudo-first-order model

- RB

Pseudo-second-order model

- RB

- RB-PDOM

— RB-MDOM

(c)

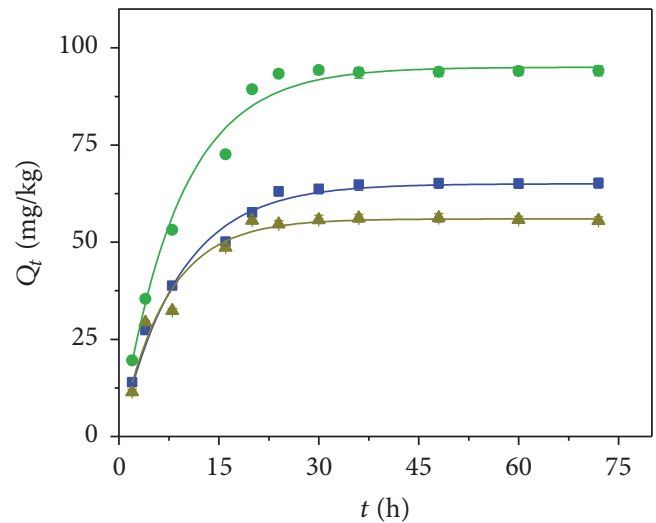

Pseudo-first-order model

- RB

- RB-PDOM

- RB-MDOM

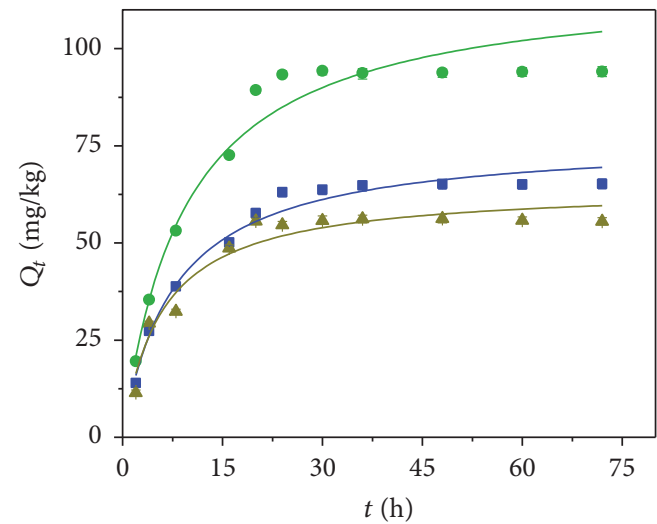

Pseudo-second-order model

— RB

- RB-PDOM

— RB-MDOM

(e)

(f)

FiguRE 2: Effects of dissolved organic matter (DOM) on sorption kinetics of oxytetracycline to first terraces (FT) (a, b), riverbed (RB) (c, d), and river floodplain (RF) (e,f) sediment. FT-PDOM, RF-PDOM, and RB-PDOM refers to the sorption with the presence of corrupt plant derived DOM (PDOM). FT-MDOM, RF-MDOM, and RB-MDOM refers to the sorption with the presence of chicken manure derived DOM (MDOM). 
TABLE 2: Pseudo-first-order and pseudo-second-order model fitted parameters for oxytetracycline sorption to three sediments with the presence of DOMs.

\begin{tabular}{lccccccccc}
\hline Samples & $Q_{e, \exp }$ & \multicolumn{3}{c}{ Pseudo-first-order model } & \multicolumn{4}{c}{ Pseudo-second-order model } \\
& $(\mathrm{mg} / \mathrm{kg})$ & $R^{2}$ & $\begin{array}{c}k_{1} \\
(1 / \mathrm{h})\end{array}$ & $\begin{array}{c}Q_{e, \mathrm{cal}} \\
(\mathrm{mg} / \mathrm{kg})\end{array}$ & $\mathrm{RSS} / \mathrm{dof}$ & $R^{2}$ & \multicolumn{2}{c}{$\begin{array}{c}k_{2} \\
(\mathrm{~kg} / \mathrm{mg} \cdot \mathrm{h})\end{array}$} & $\begin{array}{c}Q_{e, \mathrm{cal}}(\mathrm{mg} / \mathrm{kg}) \\
\mathrm{RSS} / \mathrm{dof}\end{array}$ \\
\hline FT & 40.027 & 0.9738 & 0.1695 & 38.618 & 101.663 & 0.9858 & 0.0040 & 45.684 & 55.278 \\
FT-PDOM & 61.209 & 0.9868 & 0.1695 & 60.121 & 118.341 & 0.9814 & 0.0023 & 70.417 & 166.769 \\
FT-MDOM & 37.190 & 0.9750 & 0.1502 & 36.588 & 101.698 & 0.9772 & 0.0034 & 43.441 & 93.081 \\
\hline RB & 30.089 & 0.9410 & 0.1644 & 28.652 & 49.604 & 0.9789 & 0.0061 & 32.802 & 17.755 \\
RB-PDOM & 40.027 & 0.9453 & 0.1311 & 38.943 & 145.568 & 0.9683 & 0.0033 & 45.400 & 84.239 \\
RB-MDOM & 28.133 & 0.9458 & 0.1701 & 27.193 & 63.592 & 0.9729 & 0.0065 & 31.157 & 31.771 \\
\hline RF & 65.208 & 0.9846 & 0.1121 & 65.024 & 61.865 & 0.9828 & 0.0017 & 76.862 & 68.885 \\
RF-PDOM & 94.121 & 0.9905 & 0.1129 & 95.029 & 266.481 & 0.9839 & $9.12 \mathrm{E}-4$ & 117.880 & 450.348 \\
RF-MDOM & 55.521 & 0.9420 & 0.1423 & 55.988 & 221.475 & 0.9337 & 0.0027 & 64.432 & 252.881 \\
\hline
\end{tabular}

TABLE 3: Langmuir isotherm model and Freundlich isotherm model fitted parameters for oxytetracycline sorption to three sediments with the presence of DOMs.

\begin{tabular}{|c|c|c|c|c|c|c|c|c|c|}
\hline \multirow{2}{*}{ Samples } & \multicolumn{5}{|c|}{ Langmuir isotherm model } & \multicolumn{4}{|c|}{ Freundlich isotherm model } \\
\hline & $Q_{m}(\mathrm{mg} / \mathrm{kg})$ & $K_{L}(\mathrm{~L} / \mathrm{mg})$ & $R^{2}$ & RSS/dof & $R_{L}$ & $K_{F}$ & $1 / n$ & $R^{2}$ & RSS/dof \\
\hline FT & 454.919 & 0.0152 & 0.9883 & 27.1564 & $(0.759,0.940)$ & 8.1760 & 0.8628 & 0.9896 & 24.0104 \\
\hline FT-PDOM & 563.141 & 0.0225 & 0.9889 & 57.3752 & $(0.681,0.914)$ & 14.2079 & 0.8551 & 0.9825 & 98.5720 \\
\hline FT-MDOM & 323.665 & 0.0198 & 0.9898 & 60.8960 & $(0.708,0.924)$ & 7.5841 & 0.8411 & 0.9662 & 63.3506 \\
\hline $\mathrm{RB}$ & 207.996 & 0.0257 & 0.9779 & 24.3801 & $(0.651,0.903)$ & 6.7888 & 0.7898 & 0.9789 & 23.2086 \\
\hline RB-PDOM & 287.087 & 0.0237 & 0.9945 & 10.1586 & $(0.669,0.910)$ & 8.2462 & 0.8162 & 0.9926 & 13.6067 \\
\hline RB-MDOM & 174.721 & 0.0334 & 0.9469 & 58.8434 & $(0.590,0.878)$ & 7.5521 & 0.7537 & 0.9445 & 61.3908 \\
\hline $\mathrm{RF}$ & 536.867 & 0.0165 & 0.9701 & 179.9477 & $(0.744,0.936)$ & 14.6219 & 0.8530 & 0.9589 & 247.1996 \\
\hline RF-PDOM & 688.969 & 0.0352 & 0.9549 & 567.9393 & $(0.577,0.872)$ & 26.4432 & 0.8302 & 0.9395 & 760.5967 \\
\hline RF-MDOM & 426.129 & 0.0244 & 0.9625 & 149.7934 & $(0.663,0.908)$ & 11.1970 & 0.8354 & 0.9570 & 171.7898 \\
\hline
\end{tabular}

listed in Table 2. The results showed that the sorption kinetic of OTC to RF sediments (without DOM) was fitted well to pseudo-first-order model for the greater value of $R^{2}$ and lower value of residual sum of squares (RSS/dof). The fitted theoretical equilibrium adsorption capacity $\left(Q_{e, \text { cal }}\right)$ is also closer to the actual equilibrium adsorption capacity $\left(Q_{e, \exp }\right)$, while FT and RB sediments were fitted well to pseudosecond-order model. After the PDOM was added, $R^{2}$ of pseudo-first-order model was higher than that of pseudosecond-order model. $Q_{e \text {,cal }}$ of the pseudo-first-order model was 60.121, which was closer to the $Q_{e, \exp }$ value of 61.209 than that of the value of 70.417 obtained by the pseudo-secondorder model. The RSS/dof value of the former was 118.341, lower than that of the latter value of 166.769 , so the sorption kinetic of OTC to FT sediments fitted better with pseudofirst-order with the addition of PDOM. Comparing to the sorption process without PDOM, the kinetic changed from pseudo-second-order to pseudo-first-order model. Similarly, after MDOM addition, the sorption kinetic of OTC to RF sediments was also changed from pseudo-second-order to pseudo-first-order model. This suggests that the adsorption process of these two sediments was controlled by binary factors (may be the surface active sites of the adsorbent and the solution concentration) changed to mono controlling (the sites or the solution concentration only), after the DOM was added.

3.2.2. Effect on Sorption Isotherms. Freundlich and Langmuir isotherm models, which can be applicable to describe heterogeneous systems and reversible adsorption, and monolayer adsorption on a homogeneous surface, respectively, were employed to fit the experimental data of OTC [26]. Both Freundlich and Langmuir isotherm models fitted well to sorption isotherms of OTC with regression coefficients $R^{2}>$ 0.93 (Figure 3, Table 3) whether the DOMs were added or not, indicating that the addition of DOMs would not change the isotherm models.

With the increasing of OTC equilibrium concentration $\left(C_{e}\right)$, the saturated adsorption capacity $\left(Q_{e}\right)$ of the three sediments was also increased (Figure 3). However, there is a significant difference for the effects of the maximum adsorption amount of three sediments with two kinds of DOMs. After the PDOM was added, the adsorption capacity of FT sediment increased by $23.8 \%$, and this value is $38.0 \%$ for $\mathrm{RB}$ sediment and $28.3 \%$ for RF, respectively (Table 3 ). While the MDOM was added, the adsorption capacity of FT sediment decreased by $23.3 \%$, with similar decrease of $11.6 \%$ for $\mathrm{RB}$ sediment and $16.1 \%$ for RF sediment, respectively, 

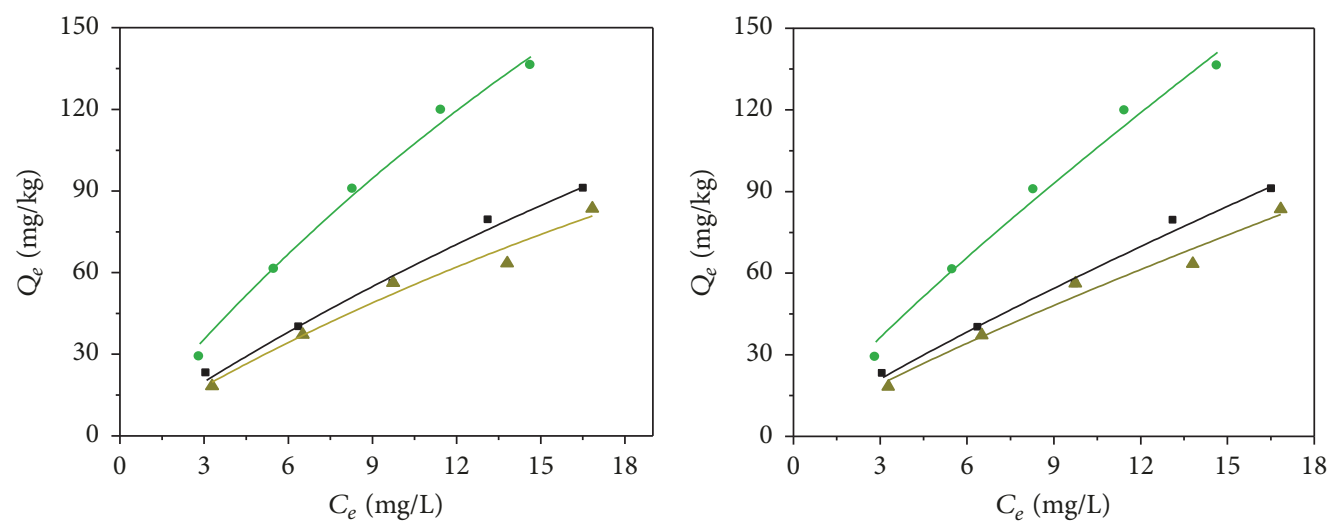

FT-Langmuir

- FT

- FT-PDOM

_ FT-MDOM

FT-Freundlich

- FT

— FT-PDOM

— FT-MDOM

(a)
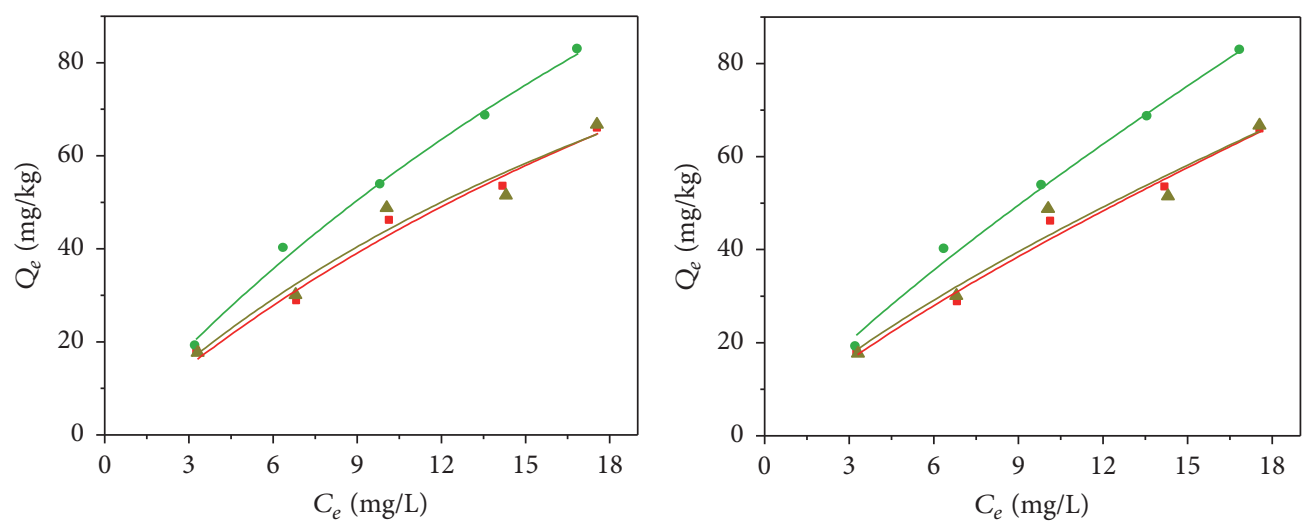

RB-Langmuir

_ RB

- RB-PDOM

— RB-MDOM

(c)

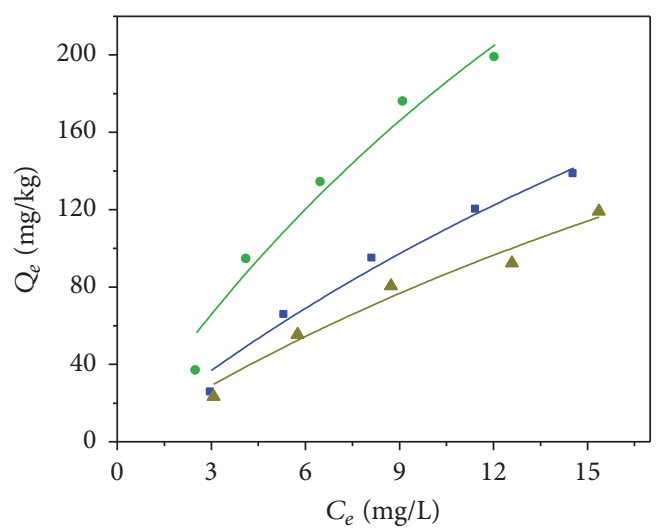

RB-Freundlich

- RB

- RB-PDOM

- RB-MDOM

(d)

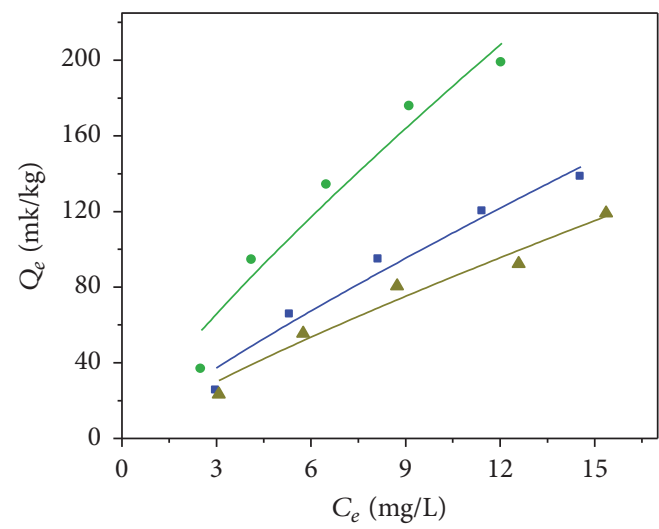

RF-Langmuir

- RF

- RF-PDOM

— RF-MDOM

RF-Freundlich

- RF

- RF-PDOM

— RF-MDOM

(e)

FIGURE 3: Effects of dissolved organic matter (DOM) on sorption isotherms of oxytetracycline to first terrace sediments (FT) (a, b), riverbed $(\mathrm{RB})(\mathrm{c}, \mathrm{d})$, and river floodplain $(\mathrm{RF})(\mathrm{e}, \mathrm{f})$. 
TABLE 4: The parameters of sorption thermodynamics of oxytetracycline to three sediments with the presence of DOMs.

\begin{tabular}{|c|c|c|c|c|c|}
\hline Samples & $T(\mathrm{~K})$ & $K$ & $\begin{array}{c}\Delta G \\
(\mathrm{~kJ} / \mathrm{mol})\end{array}$ & $\begin{array}{c}\Delta H \\
(\mathrm{~kJ} / \mathrm{mol}) \\
\end{array}$ & $\begin{array}{c}\Delta S \\
\left(\mathrm{~J} \cdot \mathrm{mol} \cdot \mathrm{K}^{-1}\right)\end{array}$ \\
\hline \multirow{3}{*}{ FT } & 298 & 5.1985 & -4.084 & \multirow{3}{*}{39.417} & \multirow{3}{*}{0.146} \\
\hline & 308 & 9.6358 & -5.801 & & \\
\hline & 318 & 14.1700 & -7.009 & & \\
\hline \multirow{3}{*}{ FT-PDOM } & 298 & 9.1670 & -5.489 & \multirow{3}{*}{35.796} & \multirow{3}{*}{0.139} \\
\hline & 308 & 15.217 & -6.971 & & \\
\hline & 318 & 22.761 & -8.262 & & \\
\hline \multirow{3}{*}{ FT-MDOM } & 298 & 4.5200 & -3.737 & \multirow{3}{*}{38.559} & \multirow{3}{*}{0.141} \\
\hline & 308 & 6.3480 & -4.733 & & \\
\hline & 318 & 11.9860 & -6.567 & & \\
\hline \multirow{3}{*}{$\mathrm{RB}$} & 298 & 3.3407 & -2.988 & \multirow{3}{*}{38.568} & \multirow{3}{*}{0.139} \\
\hline & 308 & 5.1806 & -4.212 & & \\
\hline & 318 & 8.8799 & -5.774 & & \\
\hline \multirow{3}{*}{ RB-PDOM } & 298 & 4.5150 & -3.735 & \multirow{3}{*}{33.599} & \multirow{3}{*}{0.125} \\
\hline & 308 & 6.7050 & -4.873 & & \\
\hline & 318 & 10.584 & -6.238 & & \\
\hline \multirow{3}{*}{ RB-MDOM } & 298 & 3.2920 & -2.952 & \multirow{3}{*}{38.280} & \multirow{3}{*}{0.138} \\
\hline & 308 & 5.0800 & -4.162 & & \\
\hline & 318 & 8.6850 & -5.715 & & \\
\hline \multirow{3}{*}{ RF } & 298 & 9.4643 & -5.568 & \multirow{3}{*}{31.838} & \multirow{3}{*}{0.125} \\
\hline & 308 & 13.0460 & -6.577 & & \\
\hline & 318 & 21.1930 & -8.073 & & \\
\hline \multirow{3}{*}{ RF-PDOM } & 298 & 16.4380 & -6.936 & \multirow{3}{*}{33.751} & \multirow{3}{*}{0.136} \\
\hline & 308 & 23.6930 & -8.105 & & \\
\hline & 318 & 38.6570 & -9.663 & & \\
\hline \multirow{3}{*}{ RF-MDOM } & 298 & 7.1801 & -4.884 & \multirow{3}{*}{13.376} & \multirow{3}{*}{0.061} \\
\hline & 308 & 8.3985 & -5.449 & & \\
\hline & 318 & 10.0790 & -6.109 & & \\
\hline
\end{tabular}

indicating that the adsorption of OTC could be promoted by adding PDOM, whereas the addition of MDOM could inhibit the adsorption.

3.2.3. Effect on Sorption Thermodynamics. The effects of temperature on the adsorption behavior were plotted in Figure 4 . The adsorption capacity of OTC was consistent with the increase of temperature whether the DOM is added or not; that is, with the increase of temperature, the adsorption capacity increased, and at $318 \mathrm{~K}$, the adsorption amount was the highest. The sorption capacity of the sediments followed the order: RF $>$ FT $>$ RB sediments at three temperatures. The maximum adsorption capacity of FT, RB, and RF sediment without DOMs fitted Langmuir models reached $776.015 \mathrm{mg} / \mathrm{kg}, 437.020 \mathrm{mg} / \mathrm{kg}$, and $1182.468 \mathrm{mg} / \mathrm{kg}$, respectively, at $318 \mathrm{~K}$, which is increased by 1.203 times, 1.101 times, and 0.705 times for FT, RB, and RF, respectively, at $298 \mathrm{~K}$. When the PDOM was added, the maximum adsorption capacity of three sediments of FT, RB, and RF reached $1056.176 \mathrm{mg} / \mathrm{kg}, 549.200 \mathrm{mg} / \mathrm{kg}$, and $1350.031 \mathrm{mg} / \mathrm{kg}$, respectively, at $318 \mathrm{~K}$, which is increased by $0.876,0.913$, and
0.960 times compared to that at $298 \mathrm{~K}$, respectively. When the MDOM was added, the maximum adsorption capacity of FT, $\mathrm{RB}$, and $\mathrm{RF}$ in turn reached $538.410 \mathrm{mg} / \mathrm{kg}, 404.072 \mathrm{mg} / \mathrm{kg}$, and $673.726 \mathrm{mg} / \mathrm{kg}$ at $318 \mathrm{~K}$, which also increased by 0.663 times, 1.313 times, and 0.581 times compared to that at $298 \mathrm{~K}$. Overall, the adsorption behavior of OTC to sediments responding to temperatures was changed with the addition of DOMs.

The thermodynamic parameters shown in Table 4 apparently displayed that the value of $\Delta G$ ranged from $-9.663 \mathrm{~kJ} / \mathrm{mol}$ to $-2.952 \mathrm{~kJ} / \mathrm{mol}$ for the adsorption process under three temperatures $(298 \mathrm{~K}, 308 \mathrm{~K}$, and $318 \mathrm{~K})$ with the addition of DOMs. Jaycock et al. [27, 28] reported that the change of free energy for physical adsorption is smaller than that for chemisorption. The former is in the range of $-20 \mathrm{~kJ} / \mathrm{mol} \sim 0$, and the latter is in the range of -80 to $-400 \mathrm{~kJ} / \mathrm{mol}$. So the adsorption process of OTC to sediments in this study is spontaneous, which was dominated mainly by physical adsorption. All the values of $\Delta H>0$ indicated that the adsorption process is endothermic. With the increase of temperature, the value of $\Delta G$ gradually decreases, indicating 


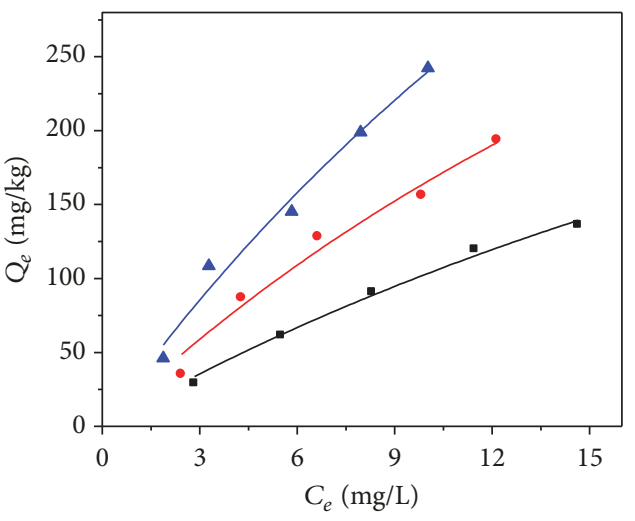

FT-PDOM Langmuir

- $298 \mathrm{~K}$

- $308 \mathrm{~K}$

$-318 \mathrm{~K}$

(a)

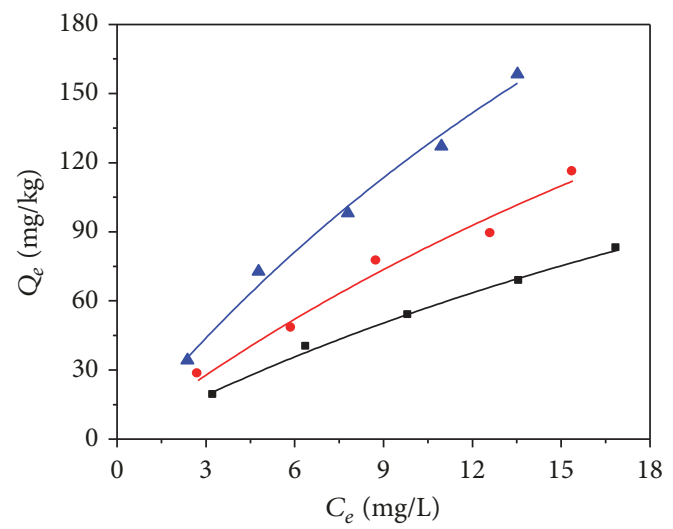

RB-PDOM Langmuir

- $298 \mathrm{~K}$

- $308 \mathrm{~K}$

$-318 \mathrm{~K}$

(c)

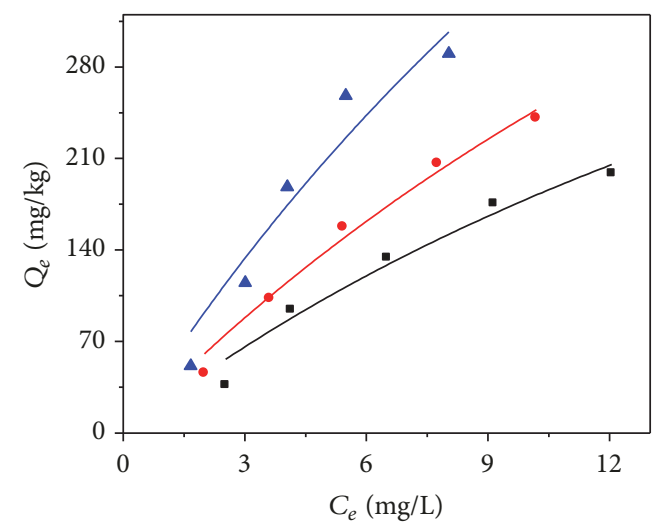

RF-PDOM Langmuir

$-\quad 298 \mathrm{~K}$
$-\quad 308 \mathrm{~K}$

- $318 \mathrm{~K}$

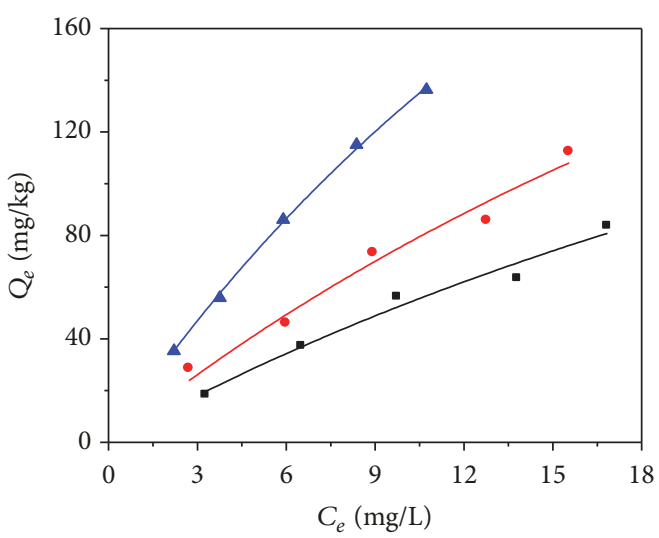

FT-MDOM Langmuir

- $298 \mathrm{~K}$

- $308 \mathrm{~K}$

$-318 \mathrm{~K}$

(b)

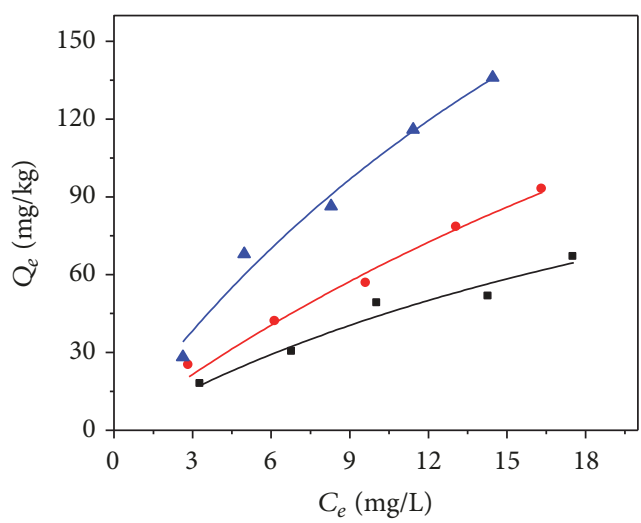

RB-MDOM Langmuir

- $298 \mathrm{~K}$

$-308 \mathrm{~K}$

$-318 \mathrm{~K}$

(d)

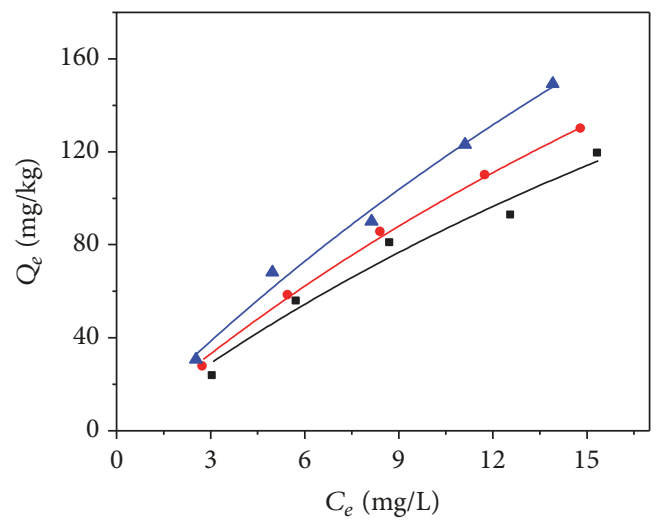

RF-MDOM Langmuir

$-\quad 298 \mathrm{~K}$
$-\quad 308 \mathrm{~K}$
$-\quad 318 \mathrm{~K}$

(e)

(f)

FIGURE 4: Effects of dissolved organic matter (DOM) on sorption thermodynamics of oxytetracycline to first terrace (FT) (a, b), riverbed $(\mathrm{RB})(\mathrm{c}, \mathrm{d})$, and river floodplain $(\mathrm{RF})(\mathrm{e}, \mathrm{f})$ sediments. 
TABLE 5: The locations of five kinds of peaks and their significance.

\begin{tabular}{|c|c|c|c|}
\hline Peaks & $\begin{array}{c}F_{\max }-E x / E m \\
(n m)\end{array}$ & Significance & Main source and properties \\
\hline P1 & $270 / 315$ & Protein-like & $\begin{array}{l}\text { Site production, anthropogenic } \\
\text { effluent-biodegradable }\end{array}$ \\
\hline $\mathrm{P} 2$ & $285 / 350$ & Protein-like & $\begin{array}{l}\text { Site production, anthropogenic } \\
\text { effluent-biodegradable }\end{array}$ \\
\hline $\mathrm{H} 1$ & $\begin{array}{l}315(250) / 400 \\
230 / 430 \\
280 / 380-460\end{array}$ & Humus-like & $\begin{array}{c}\text { Agricultural land, sewage-easy photolysis, poor } \\
\text { bioavailability }\end{array}$ \\
\hline $\mathrm{H} 2$ & $\begin{array}{c}350(280) / 460 \\
320 / 366 \\
420 / 480\end{array}$ & Humus-like & $\begin{array}{l}\text { Land-based, easy photodegradation, poor } \\
\text { bioavailability }\end{array}$ \\
\hline $\mathrm{H} 3$ & $350 / 450-485$ & Humus-like & $\begin{array}{c}\text { Land-based, the degree of degradation is relatively } \\
\text { abundant, widely spread in the water, } \\
\text { photodegradable }\end{array}$ \\
\hline
\end{tabular}

$F_{\max }()$ refers to the wavelength of secondly high fluorescence peaks.

that the higher temperature reflects a higher spontaneous degree of reaction; that is, the elevated temperature is favorable for the adsorption. In addition, the values of $\Delta G$ for the sorption process followed the order: the process of MDOM $>$ without DOMs > PDOM, indicating that the spontaneous degree of the adsorption was PDOM > without DOMs > MDOM, which also means that the adsorption of OTC could be promoted by adding PDOM, whereas the addition of MDOM could inhibit the adsorption.

3.2.4. Effect of DOM Concentration on Adsorption. To further explore the role of DOM on the sorption of OTC to sediments, single point sorption experiments were conducted under different concentration of DOM ranging from 0 to $300 \mathrm{mg}$ TOC/L. The results showed that the presence of PDOM enhanced the adsorption of OTC to sediments in all examined concentrations, and the concentration ranging from 100 to $200 \mathrm{mg}$ TOC/L related to a more obvious enhancement (Figure 5), indicating that the appropriate concentration of PDOM promoted a better effect; Jia et al. [5] reported that humic acid could be adsorbed by the sediments through $\pi-\pi$ interaction. The excessive adsorbed PDOM could block pores and compete with OTC for adsorption sites on sediments, so the promotion was no more obvious. However, the adsorption amount of OTC adsorbed to three sediments decreased with increasing concentration of MDOM, and the inhibition to RF sediments is more obvious than FT and RB sediments.

\subsection{Analysis for the Mechanism of the Adsorption}

3.3.1. 3D Fluorescence Characteristics of DOMs. Two different peaks were identified in the three-dimensional fluorescence spectra of the two DOMs (Figure 6). Actually, many studies have investigated the location and significance of fluorescence peaks (Table 5) [29-34]. The PDOM can promote the adsorption of OTC to sediments, because it has a highintensity $\mathrm{H} 3$ peak at $\mathrm{Ex} / \mathrm{Em}=340 / 430$, which was assigned

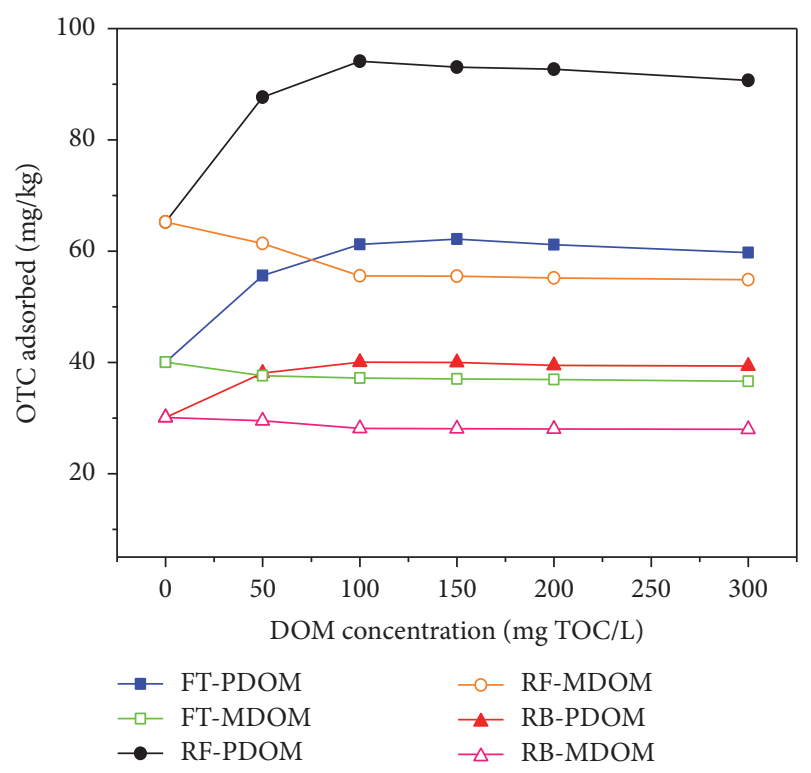

FIGURE 5: Effects of the presence of dissolved organic matters (DOM) on the sorption of oxytetracycline to first terrace (FT), river floodplain (RF), and riverbed (RB) sediments.

to a large number of humus-like substances. The result was consistent with our previous study that the humic acid could accelerate the adsorption of OTC to sediment [35], as well as its effect of tetracycline to montmorillonite reported by Zhao et al. [36], while the MDOM can inhibit the adsorption, because it has two $\mathrm{P} 2$ peaks at $\mathrm{Ex} / \mathrm{Em}=280 / 320$ and a highintensity peak at $\mathrm{Ex} / \mathrm{Em}=230 / 320$, which were denoted as a large amount of protein-like substances. These results were in agreement with the effect of pig slurry on the sorption of sulfonamide antibiotics to soil [16] and chicken manure on the sorption of OTC [37].

3.3.2. Elemental Analysis. To investigate the characterization of two DOMs, the elemental analysis was conducted. The 


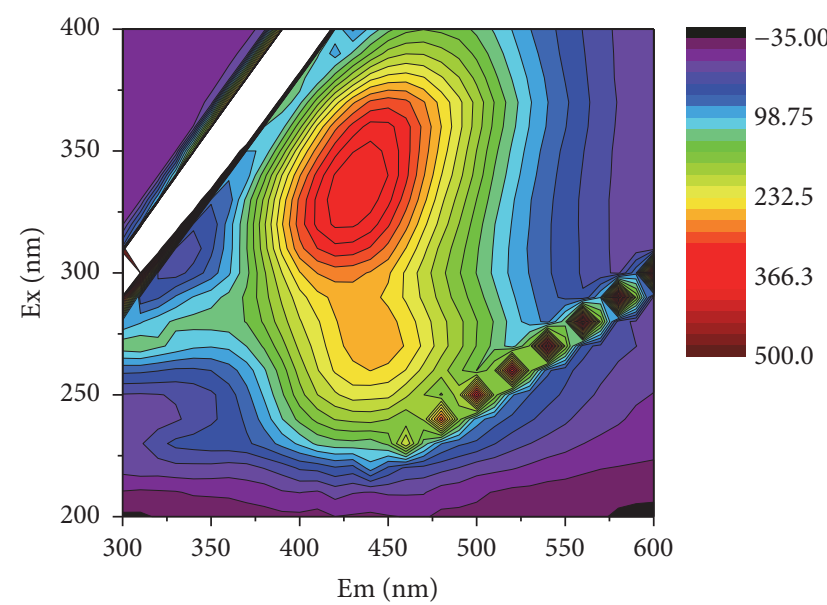

(a)

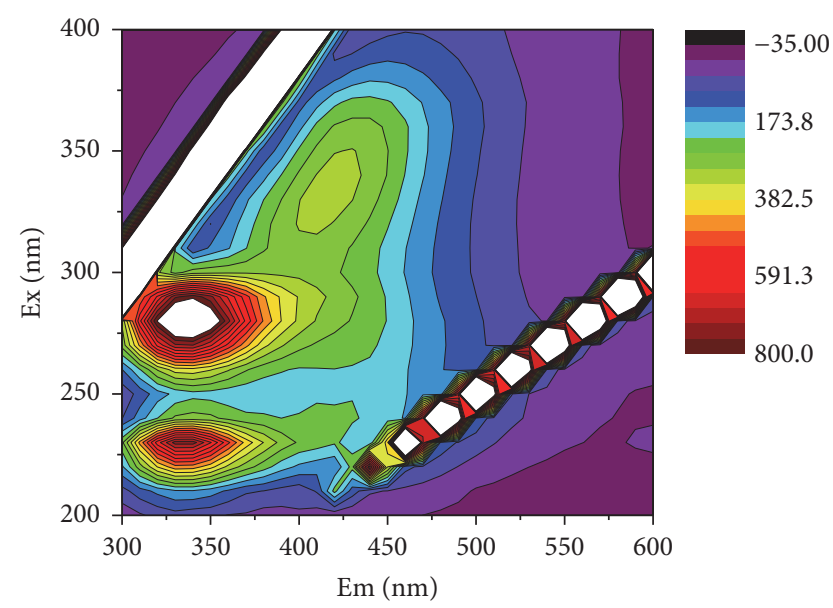

(b)

FIGURE 6: The 3D fluorescence spectra of (a) corrupt plant derived DOM (PDOM); (b) chicken manure derived DOM (MDOM).

TABLE 6: Elemental composition of corrupt plant derived DOM (PDOM) and chicken manure derived DOM (MDOM).

\begin{tabular}{lcccccrr}
\hline Samples & $\mathrm{N}(\%)$ & $\mathrm{C}(\%)$ & $\mathrm{H}(\%)$ & $\mathrm{O}(\%)$ & $\mathrm{H} / \mathrm{C}$ & $(\mathrm{N}+\mathrm{O}) / \mathrm{C}$ & 0.084 \\
\hline PDOM & 1.706 & 23.483 & 2.905 & 0.256 & 0.124 & 0.011 \\
MDOM & 1.977 & 9.490 & 1.951 & 0.122 & 0.206 & 0.152 & 0.013 \\
\hline
\end{tabular}

larger value of $(\mathrm{N}+\mathrm{O}) / \mathrm{C}$ reflects the samples with higher polarity, while larger value of $\mathrm{H} / \mathrm{C}$ indicates a lower aromaticity. The larger value of $\mathrm{O} / \mathrm{C}$ reflects a higher hydrophilicity. Two samples contained a large amount of $\mathrm{C}$ content while $\mathrm{O}$ content is relatively small (Table 6). Compared with the MDOM, the PDOM has the higher $\mathrm{C}, \mathrm{H}$ contents, whereas the content of $\mathrm{N}$ is low, which is consistent with the source of this kind of DOM.

Considering that the $\mathrm{H} / \mathrm{C}$ value of the PDOM is smaller, its high aromaticity leads to an easier combination with the sediment, so as to increase the number of adsorption sites and promote the adsorption of OTC. For the chicken manure, it has a higher value of $(\mathrm{N}+\mathrm{O}) / \mathrm{C}, \mathrm{O} / \mathrm{C}$. Its hydrophilicity and polarity are higher, which can not only promote the dissolution of pollutants in the water, but also improve its mobility, suggesting that the chicken manure DOM inhibits the adsorption of OTC to sediments.

\section{Conclusions}

The following conclusions can be drawn from the current study:

(1) The presence of DOMs can reduce the adsorption equilibrium time about $6 \mathrm{hrs}$ and can change the sorption kinetics. Both Freundlich and Langmuir isotherm models fitted to sorption isotherms of OTC well and the addition of DOMs would not change the isotherm models. The adsorption of OTC could be promoted by adding PDOM, whereas the addition of MDOM could inhibit the adsorption. The adsorption processes are all endothermic, spontaneous, and mainly physical adsorption. The spontaneous degree of the adsorption process followed the order: $\mathrm{PDOM}>$ without DOMs > MDOM.

(2) Comparing the adsorption mechanism of the two kinds of DOM, it was found that the PDOM has high aromaticity, low hydrophilicity, and polarity because it consists of humus-like substances, leading to an easier combination with the sediment, so as to increase the number of adsorption sites and promote the adsorption of OTC. The MDOM has high hydrophilicity and polarity because it consists of protein-like substances, which can promote the dissolution of pollutants in the water and improve its mobility. It suggested that the chicken manure DOM inhibits the adsorption of OTC to sediments; that is, the humus-like dominated DOM can promote the adsorption of OTC, while the proteinlike dominated DOM can inhibit the adsorption of OTC to sediments.

\section{Conflicts of Interest}

The authors declare that there are no conflicts of interest regarding the publication of this article.

\section{Acknowledgments}

The work was financially supported by National Natural Science Foundation of China (no. 41372259 and no. 41672224), the National Key Research and Development Program of China (no. 2016YFC0400701), the Fundamental Research Funds for the Central Universitis (no. GK201703052), China Postdoctoral Science Foundation (no. 2017M613048), and Shaanxi postdoctoral research funding project in China (no. 2017BSHTDZZ03). 


\section{References}

[1] A. K. Sarmah, M. T. Meyer, and A. B. A. Boxall, "A global perspective on the use, sales, exposure pathways, occurrence, fate and effects of veterinary antibiotics (VAs) in the environment," Chemosphere, vol. 65, no. 5, pp. 725-759, 2006.

[2] S. Q. Zhang, F. D. Zhang, and X. M. Liu, "Determination and analysis on main harmful composition in excrement of scale livestock and poultry feedlots," Plant Nutrition Fertilizing Science, vol. 11, no. 6, pp. 822-829, 2005.

[3] R. Wang, T.-Z. Liu, and T. Wang, "The fate of antibiotics in environment and its ecotoxicology: A review," Acta Ecologica Sinica, vol. 26, no. 1, pp. 265-269, 2006 (Chinese).

[4] Y.-Y. Bao, Q.-X. Zhou, Y. Wan, Q. Yu, and X.-J. Xie, "Adsorption and desorption of three tetracycline antibiotics in cinnamon soils of China," China Environmental Science, vol. 30, no. 10, pp. 1383-1388, 2010 (Chinese).

[5] M. Jia, F. Wang, Y. Bian et al., "Sorption of sulfamethazine to biochars as affected by dissolved organic matters of different origin," Bioresource Technology, 2017.

[6] M. Kühne, D. Ihnen, G. Möller, and O. Agthe, "Stability of Tetracycline in Water and Liquid Manure," Journal of Veterinary Medicine Series A: Physiology Pathology Clinical Medicine, vol. 47, no. 6, pp. 379-384, 2000.

[7] S. Oh, W. S. Shin, and H. T. Kim, "Effects of pH, dissolved organic matter, and salinity on ibuprofen sorption on sediment," Environmental Science and Pollution Research, vol. 23, no. 22, pp. 22882-22889, 2016.

[8] P. Kulshrestha, R. F. Giese Jr., and D. S. Aga, "Investigating the molecular interactions of oxytetracycline in clay and organic matter: Insights on factors affecting its mobility in soil," Environmental Science \& Technology, vol. 38, no. 15, pp. 4097-4105, 2004.

[9] K.-L. Chen, L.-C. Liu, and W.-R. Chen, "Adsorption of sulfamethoxazole and sulfapyridine antibiotics in high organic content soils," Environmental Pollution, vol. 231, pp. 1163-1171, 2017.

[10] C. T. Chiou, R. L. Malcolm, T. I. Brinton, and D. E. Kile, "Water solubility enhancement of some organic pollutants and pesticides by dissolved humic and fulvic acids," Environmental Science \& Technology, vol. 20, no. 5, pp. 502-508, 1986.

[11] S. D. Nelson, J. Letey, W. J. Farmer, C. F. Williams, and M. Ben-Hur, "Facilitated transport of napropamide by dissolved organic matter in sewage sludge-amended soil," Journal of Environmental Quality, vol. 27, no. 5, pp. 1194-1200, 1998.

[12] C. F. Williams, M. Agassi, J. Letey, W. J. Farmer, S. D. Nelson, and M. Ben-Hur, "Facilitated transport of napropamide by dissolved organic matter through soil columns," Soil Science Society of America Journal, vol. 64, no. 2, pp. 590-594, 2000.

[13] X. Huang and L. S. Lee, "Effects of dissolved organic matter from animal waste effluent on chlorpyrifos sorption by soils," Journal of Environmental Quality, vol. 30, no. 4, pp. 1258-1265, 2001.

[14] S. Yang, L. Gao, Y. Y. Liu, Y. Zhao, H. Li, and Y. Zhou, "The influence of Humic Acid Colloid on adsorption behaviors of acetaminophen onto sediment," Fresenius Environmental Bulletin, vol. 24, no. 11B, pp. 4042-4049, 2015.

[15] C. Gao, S. Yang, W. Wang, and L. Gao, "Influence of humic acid colloid on adsorption of ddt in the riverbed sediments," Asian Journal of Chemistry, vol. 26, no. 9, pp. 2637-2642, 2014.

[16] S. Thiele-Bruhn and M.-O. Aust, "Effects of pig slurry on the sorption of sulfonamide antibiotics in soil," Archives of
Environmental Contamination and Toxicology, vol. 47, no. 1, pp. 31-39, 2004.

[17] W. Ling, J. Xu, Y. Gao, and H. Wang, "Influence of dissolved organic matter (DOM) on environmental behaviors of organic pollutants in soils," Chinese Journal of Applied Ecology, vol. 15, no. 2, pp. 326-330, 2004 (Chinese).

[18] A. Nebbioso and A. Piccolo, "Molecular characterization of dissolved organic matter (DOM): a critical review," Analytical and Bioanalytical Chemistry, vol. 405, no. 1, pp. 109-124, 2013.

[19] Y. Zielezny, J. Groeneweg, H. Vereecken, and W. Tappe, "Impact of sulfadiazine and chlorotetracycline on soil bacterial community structure and respiratory activity," Soil Biology \& Biochemistry, vol. 38, no. 8, pp. 2372-2380, 2006.

[20] P. K. Jjemba, "The potential impact of veterinary and human therapeutic agents in manure and biosolids on plants grown on arable land: a review," Agriculture, Ecosystems \& Environment, vol. 93, no. 1-3, pp. 267-278, 2002.

[21] M. Chen, W. Tang, C. Ge, and L. Peng, "Effects of biochar made from bagasse on adsorption behavior of ofloxacin in latosols," Chinese Journal of Environmental Engineering, vol. 9, no. 10, pp. 5083-5090, 2015 (Chinese).

[22] R.-H. Qi, Z.-J. Li, J. Long, F.-F. Fan, and Y.-C. Liang, "Effects of soil trituration size on adsorption of oxytetracycline on soils," Environmental science, vol. 32, no. 2, pp. 589-595, 2011 (Chinese).

[23] T. L. Laak, W. A. Gebbink, and J. Tolls, "Estimation of soil sorption coefficients of veterinary pharmaceuticals from soil properties," Environmental Toxicology and Chemistry, vol. 25, no. 4, pp. 933-941, 2006.

[24] J. Lin, Y. Zhan, Z. Zhu, and Y. Xing, "Adsorption of tannic acid from aqueous solution onto surfactant-modified zeolite," Journal of Hazardous Materials, vol. 193, pp. 102-111, 2011.

[25] J. Y. Zhang, L. P. Liang, L. J. Pu, and et al., "Adsorption characteristics of $\mathrm{Cr}(\mathrm{VI})$ by wheat straw including kinetic and thermodynamics analysis," Research of Environmental Sciences, vol. 23, no. 12, pp. 1547-1552, 2010.

[26] M. A. Wahab, S. Jellali, and N. Jedidi, "Ammonium biosorption onto sawdust: FTIR analysis, kinetics and adsorption isotherms modeling," Bioresource Technology, vol. 101, no. 14, pp. 50705075, 2010.

[27] M. J. Jaycock and G. D. Parfitt, Chemistry of Interfaces, Ellis Horwood Limited Publisher, 1981.

[28] Y. Yu, Y.-Y. Zhuang, Z.-H. Wang, and M.-Q. Qiu, "Adsorption of water-soluble dyes onto modified resin," Chemosphere, vol. 54, no. 3, pp. 425-430, 2004.

[29] P. G. Coble, "Marine optical biogeochemistry: The chemistry of ocean color," Chemical Reviews, vol. 107, no. 2, pp. 402-418, 2007.

[30] C. A. Stedmon and S. Markager, "Resolving the variability in dissolved organic matter fluorescence in a temperate estuary and its catchment using PARAFAC analysis," Limnology and Oceanography, vol. 50, no. 2, pp. 686-697, 2005a.

[31] C. A. Stedmon and S. Markager, "Tracing the production and degradation of autochthonous fractions of dissolved organic matter by fluorescence analysis," Limnology and Oceanography, vol. 50, no. 5, pp. 1415-1426, 2005b.

[32] L. Jørgensen, C. A. Stedmon, T. Kragh, S. Markager, M. Middelboe, and M. Søndergaard, "Global trends in the fluorescence characteristics and distribution of marine dissolved organic matter," Marine Chemistry, vol. 126, no. 1-4, pp. 139-148, 2011.

[33] S. K. L. Ishii and T. H. Boyer, "Behavior of reoccurring parafac components in fluorescent dissolved organic matter in natural 
and engineered systems: A critical review," Environmental Science \& Technology, vol. 46, no. 4, pp. 2006-2017, 2012.

[34] C. A. Stedmon, B. Seredyńska-Sobecka, R. Boe-Hansen, N. Le Tallec, C. K. Waul, and E. Arvin, "A potential approach for monitoring drinking water quality from groundwater systems using organic matter fluorescence as an early warning for contamination events," Water Research, vol. 45, no. 18, pp. 60306038, 2011.

[35] L. Gao, S. Yang, D. Wang, C. Gao, and G. Wang, "Influence of humic acid colloid on adsorption of oxytetracycline in sediment," Asian Journal of Chemistry, vol. 26, no. 24, pp. 83038308, 2014.

[36] Y. Zhao, X. Gu, S. Gao, J. Geng, and X. Wang, "Adsorption of tetracycline (TC) onto montmorillonite: Cations and humic acid effects," Geoderma, vol. 183-184, pp. 12-18, 2012.

[37] Q. Kang, S. Bao, H. Wang, and et al., "Adsorption of tetracycline and zine on the soil in the dissolved organic matter-tetracyclinezinc coexistence system," Science Technology and Engineering, vol. 16, no. 14, pp. 69-73, 2016 (Chinese). 

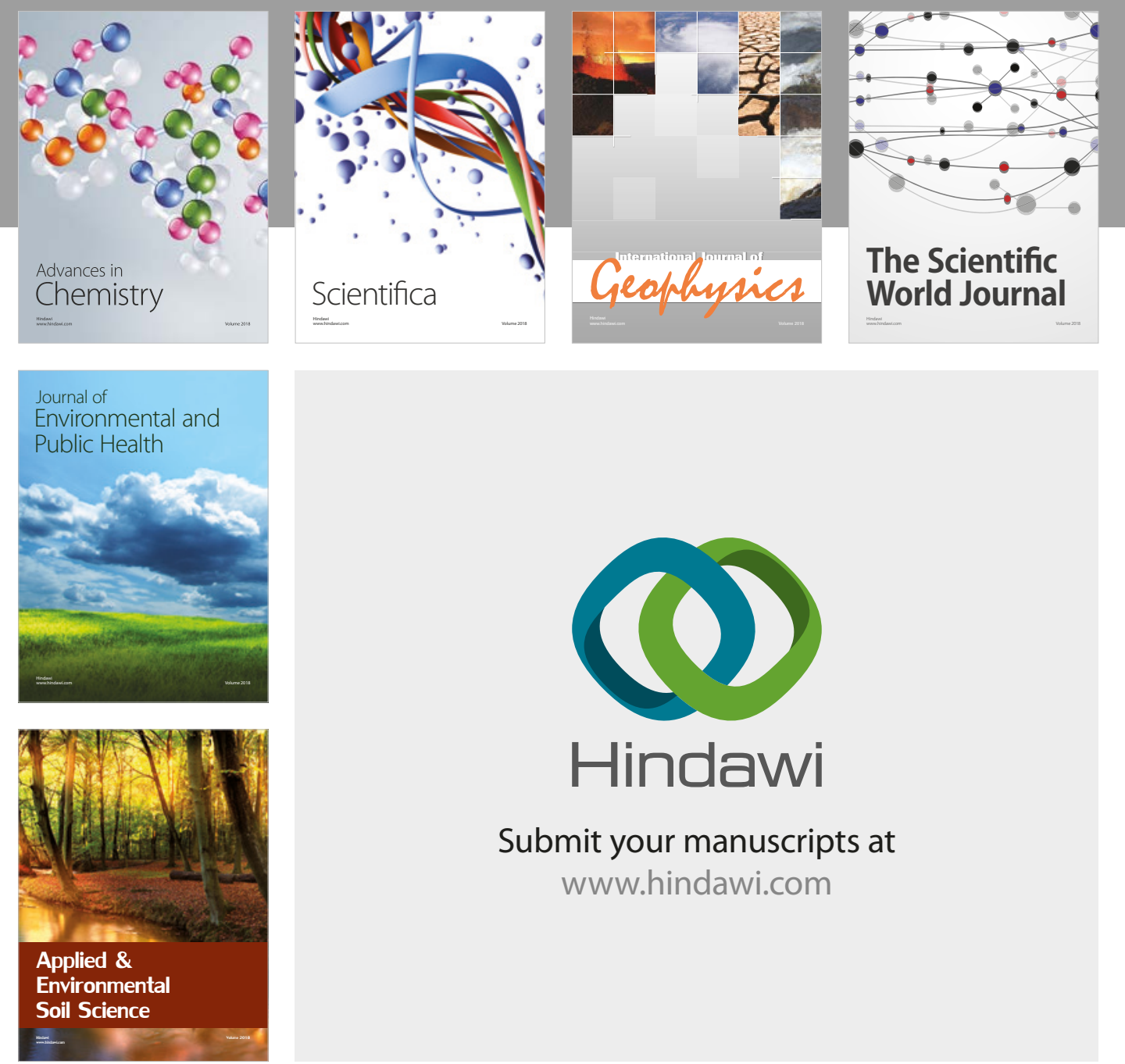

The Scientific

\section{World Journal}
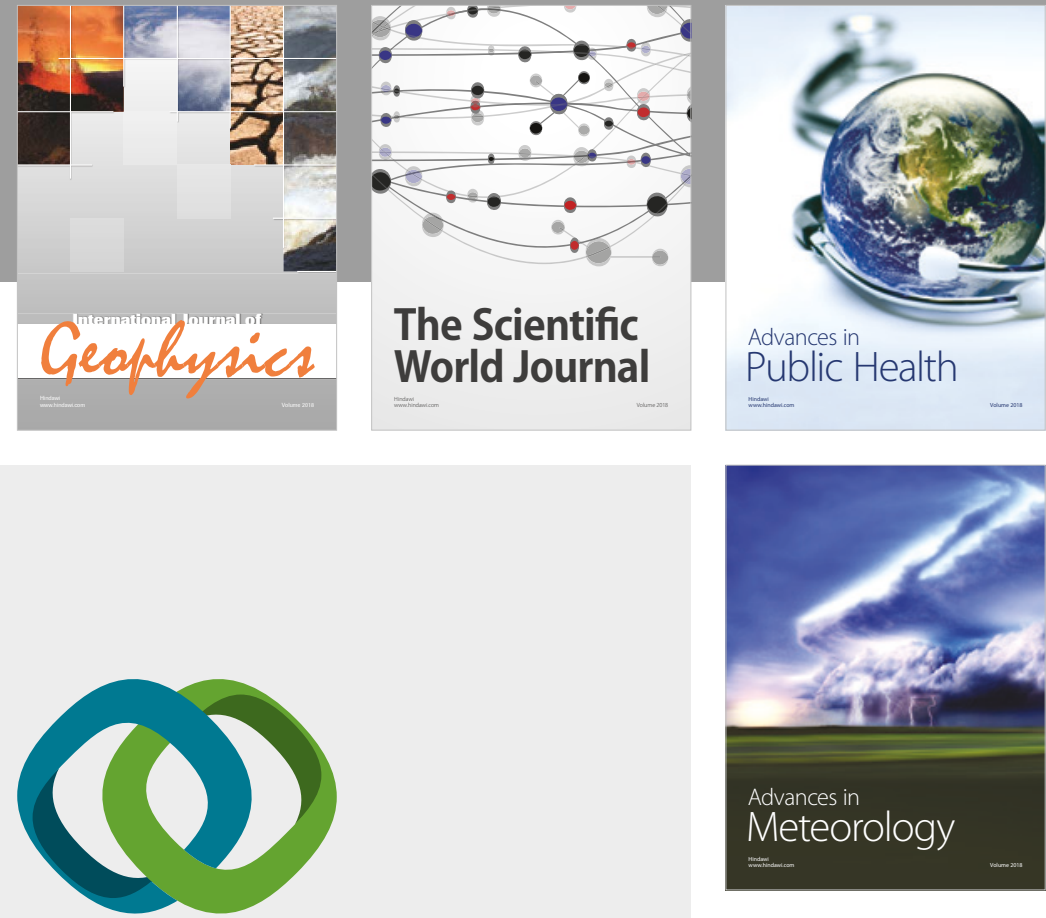

Advan

Public Health

\section{Hindawi}

Submit your manuscripts at

www.hindawi.com
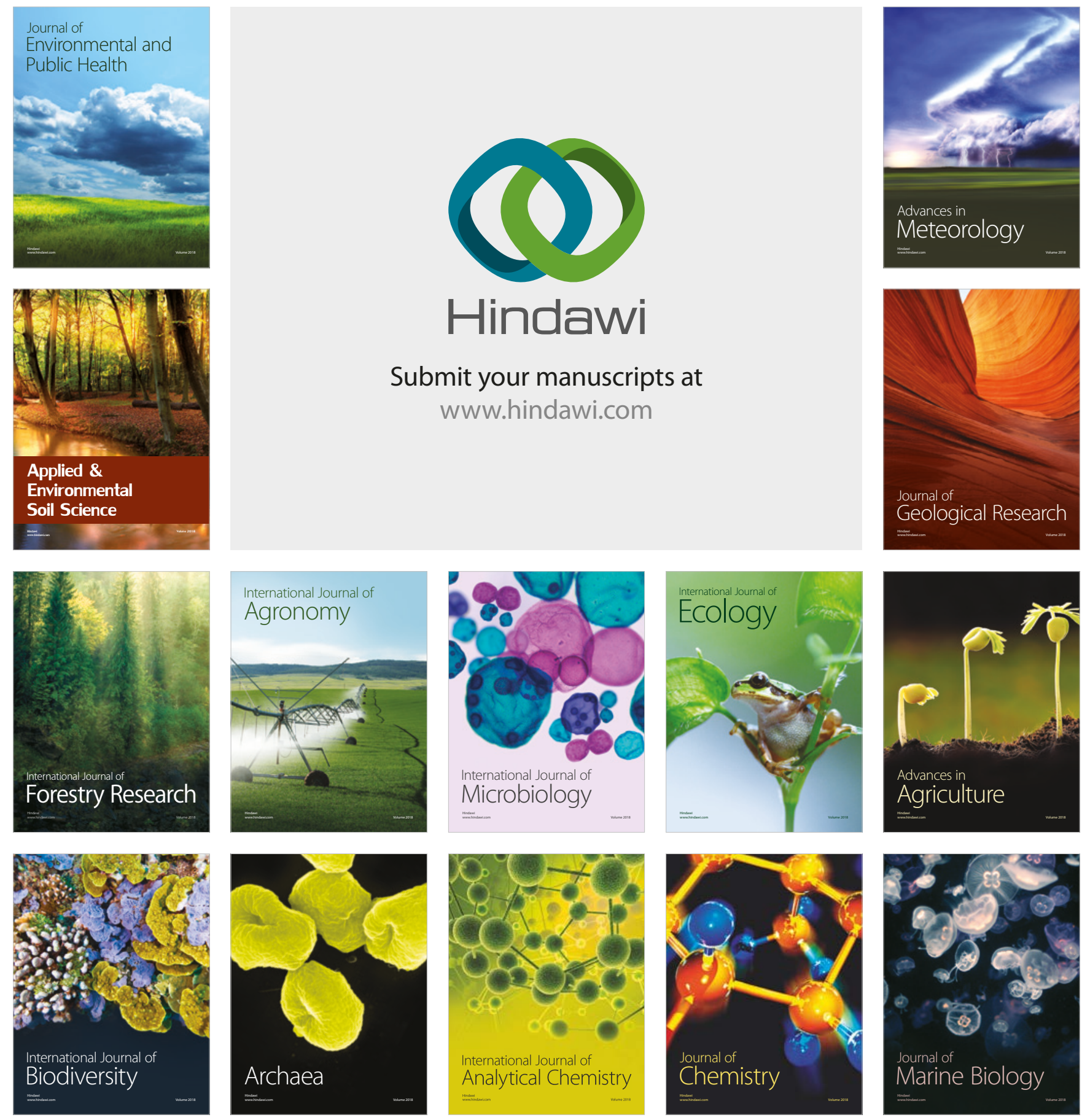